[J. Appl. Glycosci., Vol. 48, No. 4, p. 307-316 (2001)]

\title{
Molecular Structure and Pasting Properties of Normal Barley Starches
}

\author{
Yasushi Yoshimoto, ${ }^{1,2}$ Isao Hanashiro, ${ }^{3}$ Tadahiro Takenouchi ${ }^{2}$ and Yasuhito Takeda ${ }^{3, *}$ \\ ${ }^{1}$ United Graduate School of Agricultural Sciences, Kagoshima University \\ (1-21-24, Korimoto, Kagoshima 890-0065, Japan) \\ ${ }^{2}$ Takenouchi Barley Processing Inc. (4-12-4, Nan-ei, Kagoshima 891-0122, Japan) \\ ${ }^{3}$ Department of Biochemical Science and Technology, Faculty of Agriculture, Kagoshima University \\ (1-21-24, Korimoto, Kagoshima 890-0065, Japan)
}

\begin{abstract}
The molecular structure and pasting properties of the starches from seven normal cultivars of barley were examined and compared with those of normal maize, rice and wheat starches. The barley starches had an actual amylose content of 24.3-27.9\%. The starches had different pasting properties, such as maximum viscosity and breakdown, and different amylose gelatinization. A positive correlation was found between the maximum viscosity and the gelatinization degree of amylose, suggesting that low amylose gelatinization restrains the swelling of starch granules. The amylopectins had a low iodine affinity $(0.42-0.70 \mathrm{~g} / 100 \mathrm{~g})$ and resembled each other in chain-length distribution with the individual peaks of B1 and A chains. The amyloses had DPn of 810-1410 with 3.65.2 chains per molecule, indicating that barley amyloses differed in molecular structure with the cultivars. Among the cereal starches, barley starches were similar to wheat starch in amylose content and molecular structure, especially molecular size of amylose and chain-length distribution of amylopectin.
\end{abstract}

Barley is one of the major cereals along with maize, rice and wheat, and is mainly used for livestock feed and raw material for the production of alcoholic beverages. Recently, barley has also been used as food, such as a rice substitute, and in breads and noodles. Starch is the main component of barley grains (65\% by wet weight). ${ }^{1)}$ However, structural characteristics of barley starches have been less well established compared with those of other major cereals such as maize, ${ }^{2,3)}$ rice $^{4-6)}$ and wheat. $^{7.8)}$ We recently examined the molecular structure of starches from some barley cultivars with different amylose content, one waxy $(0 \%$ amylose), two low-amylose (2 and $11 \%$ amylose), two normal (23 and 25\% amylose) and two highamylose (33 and $41 \%$ amylose) barley starches. ${ }^{9,10)}$ The barley amylopectins from starches with different amylose content were similar in molecular structure, while the amyloses had different molecular structures. The amyloses from the normal culti-

\footnotetext{
${ }^{*}$ Corresponding author.
}

vars were similar in size to those of high-amylose cultivars but smaller than those of low-amylose cultivars. To date there is only limited literature in which the molecular structure of normal barley starches is examined ${ }^{9-12)}$ although many varieties are cultivated. Moreover, in most studies, ${ }^{13-18}$ their structural analyses were conducted using whole starch. In this study, seven normal barley starches were characterized in molecular structure of fractionated amylose and amylopectin and starch pasting properties in order to elucidate both similarities and differences among the normal varieties.

\section{MATERIALS AND METHODS}

Materials. The characteristics and harvest area of normal cultivars of barley are shown in Table 1 . Starch was isolated from barley grains by an alkaline steeping method. ${ }^{2)}$ Defatted starch was prepared by three replications of dissolution in dimethyl sulfoxide and precipitation with ethanol. ${ }^{4}$ Amylose and amylopectin were fractionated from 
Table 1. List of barley grains.

\begin{tabular}{lccl}
\hline \multicolumn{1}{c}{ Cultivar } & Row type & Hull & \multicolumn{1}{c}{ Harvest area } \\
\hline Schooner & 2 & $+^{a}$ & Australia (South) \\
Grimmett & 2 & + & Australia (Q. land) \\
Starling & 2 & + & Australia (West) \\
Nishinochikara & 2 & + & Japan (Kagoshima) \\
Minorimugi & 6 & + & Japan (Toyama) \\
Hinodehadaka & 6 & $-{ }^{b}$ & Japan (Ehime) \\
Aohadakamugi & 6 & - & Japan (Kagoshima) \\
\hline
\end{tabular}

${ }^{a}$ Hulled barley. ${ }^{b}$ Hull-less barley.

Table 2. Properties of barley starches.

\begin{tabular}{lcccc}
\hline \multirow{2}{*}{ Cultivar } & \multicolumn{3}{c}{ Amylose content (\%) } & \\
\cline { 2 - 4 } & $\begin{array}{c}\text { Actual }^{a} \\
(A)\end{array}$ & $\begin{array}{c}\text { Apparent }^{b} \\
(B)\end{array}$ & $B-A$ & $\begin{array}{c}\text { Crystalline } \\
\text { type }\end{array}$ \\
\hline Schooner & 27.9 & 28.5 & 0.6 & $\mathrm{~A}$ \\
Grimmett & 26.8 & 28.2 & 1.4 & $\mathrm{~A}$ \\
Starling & 26.4 & 27.9 & 1.5 & $\mathrm{~A}$ \\
Nishinochikara & 25.5 & 26.7 & 1.2 & $\mathrm{~A}$ \\
Minorimugi & 26.8 & 28.0 & 1.2 & $\mathrm{~A}$ \\
Hinodehadaka & 24.6 & 26.6 & 2.0 & $\mathrm{~A}$ \\
Aohadakamugi & 24.3 & 24.8 & 0.5 & $\mathrm{~A}$ \\
\hline
\end{tabular}

${ }^{a}$ Calculated by $[($ IAdefatted strach - IAamylopectin)/(IAamylose - IA amylopectin) $] \times 100$. IA, iodine affinity. IA values of defatted starch, amylopectin and amylose are those in Tables 6,7 , and 9 , respectively. ${ }^{b}$ Calculated by (IAdefatted strach $/ 20$ ) $\times 100$.

the defatted starch by the method of Lansky et al. ${ }^{19)}$ with modifications. ${ }^{4,5)}$ The purity of amylose was examined by gel chromatography (Toyopearl HW-75F, Tosoh, Tokyo, Japan). ${ }^{20)}$ Crystalline Pseudomonas isoamylase was the product of Hayashibara Biochemical Lab. Inc. (Okayama, Japan). $\beta$-Amylase was further purified from a commercial product (Sigma Chemical Co., St. Louis, MO) by the method of Marshall and Whelan. ${ }^{21)}$

Physicochemical analyses. Iodine affinity (IA, $\mathrm{g} / 100 \mathrm{~g}$ ) was determined by the amperometric titration method ${ }^{22)}$ with modification. ${ }^{5)}$ Pasting properties and thermal behavior of starch were determined by using a Rapid Visco Analyzer (RVA-3D, Newport Scientific, Narrabeen, Australia) and Differential Scanning Calorimetry (DSC-7, PerkinElmer, Norwalk, CT), respectively, as described elsewhere. ${ }^{9)} \mathrm{X}$-ray diffraction was performed on an X-ray diffractomer (Rotaflex RV-20013, Rigaku Denki Co., Tokyo, Japan) on wet specimens under the conditions described by Hizukuri et al. ${ }^{23)}$ The degree of gelatinization of starch paste was determined by glucoamylase digestion and iodine titration methods. ${ }^{24)}$

Analytical methods. The blue value, $\lambda_{\max }$ and $\beta$-amylolysis limit $(\beta$-AL) were determined as described previously. ${ }^{25,26)}$ The average chain-length (CL) was determined by the rapid Smith degradation $^{27,28)}$ and by hydrolysis with isoamylase. ${ }^{25)}$ The number-average degree of polymerization (DPn) of amylose was determined by the modified ParkJohnson's method. ${ }^{28)}$ The average number of chains per molecule was calculated as DPn/CL. Phosphorus was determined as inorganic phosphate ${ }^{29)}$ after treatment with hot perchloric acid. ${ }^{30}$ The chainlength distribution of amylopectin debranched with isoamylase was determined by gel-permeation HPLC with a low-angle laser-light scattering photometer and a differential refractometer, ${ }^{31)}$ and high performance anion-exchange chromatography with pulsed amperometric detection. ${ }^{32)}$ The weightaverage degree of polymerization (DPw) and the DP distribution of amylose were determined by gelpermeation HPLC. ${ }^{33)}$ Carbohydrate was determined by the phenol-sulfuric acid method. ${ }^{34)}$

\section{RESULTS AND DISCUSSION}

\section{General properties of starch.}

Table 2 summarizes the properties of seven normal barley starches. The actual amylose content, calculated from the iodine affinity (IA, g/100 g) of defatted starch, amylose and amylopectin, was $24.3-27.9 \%$. The values were similar to those reported for other normal barley cultivars (23$28 \%),{ }^{9-12)}$ but higher than those for maize (19$21 \%)^{2,3)}$ and rice $\left.(16-19 \%)\right)^{5,6)}$ and were comparable to those of wheat $(22-27 \%)^{7,8)}$ starches. The actual amylose content was slightly lower than the apparent amylose content, which was calculated without consideration of the IA of amylopectin. The difference between apparent and actual amylose content was $0.5-2.0 \%$, which was smaller than those of maize $(4-5 \%),{ }^{2,3)}$ rice $(2-10 \%)^{5,6)}$ and wheat $(1-$ 
$5 \%)^{7,8)}$ starches. This is due to a lower IA of barley amylopectins compared with those of other cereal amylopectins as described later. The lower IA suggested that barley amylopectins had fewer long chains that formed a complex with iodine.

Barley starches had A crystalline type, being the same as those of other cereal starches. ${ }^{35)}$ From the relationship between the crystalline type of starch and the average chain-length (CL) of amylopectin investigated by Hizukuri et al., ${ }^{35)}$ the CL of barley amylopectins was expected to be around or below 20.

\section{Pasting properties of starches.}

Figure 1 shows the viscograms of barley starches $(9 \%, \mathrm{w} / \mathrm{w})$ determined by a Rapid Visco Analyzer, and Table 3 the pasting properties. The pasting temperature of the barley starches was in the range of $64.4-80.5^{\circ} \mathrm{C}$, where Hinodehadaka starch had the highest temperature and Minorimugi starch the lowest. Nishinochikara starch showed the highest values for maximum viscosity, minimum viscosity and viscosity at $40^{\circ} \mathrm{C}$, and Grimmett starch showed the lowest values except for minimum viscosity. The starch having a lower maximum viscosity tended to reach the maximum viscosity at a longer time. The breakdown values were low for Grimmett, Starling and Schooner starches (12-45 RVU), but high for Hinodehadaka (102 RVU) and Aohadakamugi (133 RVU) starches. The set back values ranged from 95 to $191 \mathrm{RVU}$, and the value was highest for Minorimugi starch and lowest for Grimmett. These results showed that pasting properties of starch were

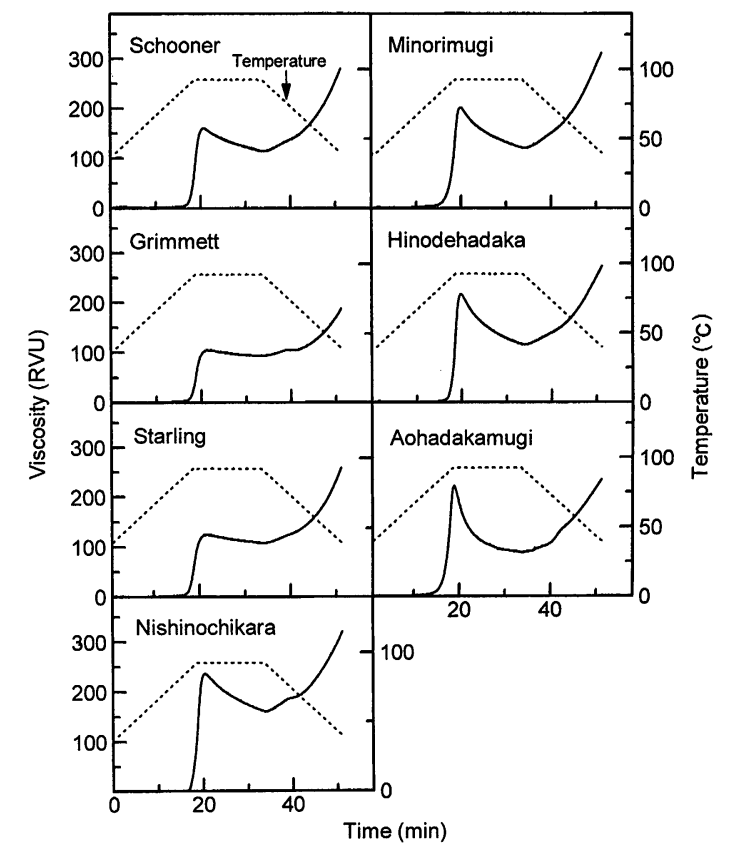

Fig. 1. Rapid viscograms of barley starches. Concentration was $9 \%(\mathrm{w} / \mathrm{w})$.

different among the cultivars of normal barley. However, the difference was much less than that between waxy and high-amylose barley starches, of which amylose contents ranged largely in $0^{-}$ $45 \% .^{9,10,18,36-38)}$ Therefore, the difference observed among the normal barley cultivars seemed to be not due to amylose content but probably due to starch granule size ${ }^{37)}$ and phospholipid content, ${ }^{38)}$ although no determination was made for the specimens in this study. As compared with other cereal starches, ${ }^{8,39,40)}$ the barley starches had lower maxi-

Table 3. Pasting properties of barley starches (conc. 9\%).

\begin{tabular}{|c|c|c|c|c|c|c|c|c|}
\hline \multirow[b]{2}{*}{ Cultivar } & \multirow{2}{*}{$\begin{array}{c}\text { Pasting } \\
\text { temperature } \\
\left.\text { ( }{ }^{\circ} \mathrm{C}\right)\end{array}$} & \multicolumn{3}{|c|}{ Maximum viscosity } & \multicolumn{2}{|c|}{ Viscosity (RVU) } & \multirow{2}{*}{$\begin{array}{l}\text { Breakdown } \\
\text { (RVU) }\end{array}$} & \multirow{2}{*}{$\begin{array}{r}\text { Set back } \\
\text { (RVU) }\end{array}$} \\
\hline & & (RVU) & $\begin{array}{c}\text { Temperature } \\
\left({ }^{\circ} \mathrm{C}\right)\end{array}$ & $\begin{array}{l}\text { Time } \\
(\min )\end{array}$ & Minimum & $40^{\circ} \mathrm{C}$ & & \\
\hline Schooner & 76.8 & 177 & 92.5 & 20.7 & 132 & 297 & 45 & 165 \\
\hline Grimmett & 72.6 & 105 & 92.5 & 21.2 & 93 & 188 & 12 & 95 \\
\hline Starling & 75.0 & 125 & 92.5 & 21.0 & 107 & 258 & 18 & 151 \\
\hline Nishinochikara & 79.9 & 254 & 92.5 & 20.4 & 178 & 339 & 76 & 161 \\
\hline Minorimugi & 64.4 & 201 & 92.5 & 19.7 & 120 & 311 & 81 & 191 \\
\hline Hinodehadaka & 80.5 & 235 & 92.5 & 19.8 & 133 & 292 & 102 & 159 \\
\hline Aohadakamugi & 66.7 & 221 & 92.5 & 18.9 & 88 & 234 & 133 & 146 \\
\hline
\end{tabular}


Table 4. The changes of degree of gelatinization of barley starch pastes.

\begin{tabular}{|c|c|c|c|c|c|c|c|c|}
\hline \multirow[t]{2}{*}{ Cultivar } & \multicolumn{4}{|c|}{$\begin{array}{c}\text { DG-g }^{a}(\%) \\
\text { Time of storage (h) }\end{array}$} & \multicolumn{4}{|c|}{$\begin{array}{c}\text { DG-i }{ }^{b}(\%) \\
\text { Time of storage }(\mathrm{h})\end{array}$} \\
\hline & 0 & 1 & 15 & 24 & 0 & 1 & 15 & 24 \\
\hline Schooner & 100 & 90 & 88 & 89 & 93 & 49 & 45 & 46 \\
\hline Grimmett & 99 & 86 & 85 & 87 & 89 & 50 & 53 & 45 \\
\hline Starling & 98 & 90 & 85 & 84 & 89 & 45 & 39 & 40 \\
\hline Nishinochikara & 99 & 93 & 91 & 90 & 99 & 58 & 41 & 41 \\
\hline Minorimugi & 100 & 92 & 88 & 89 & 99 & 67 & 48 & 47 \\
\hline Hinodehadaka & 98 & 91 & 89 & 89 & 95 & 43 & 44 & 45 \\
\hline Aohadakamugi & 98 & 91 & 90 & 91 & 97 & 60 & 55 & 49 \\
\hline
\end{tabular}

${ }^{a}$ Degree of gelatinization determined by glucoamylase method. ${ }^{b}$ Degree of gelatinization determined by iodine titration method.

Table 5. Thermal properties of barley starches.

\begin{tabular}{|c|c|c|c|c|c|c|c|c|}
\hline \multirow{2}{*}{ Cultivar } & \multicolumn{4}{|c|}{ Peak 1} & \multicolumn{4}{|c|}{ Peak 2} \\
\hline & $T \mathrm{o}^{a}\left({ }^{\circ} \mathrm{C}\right)$ & $T \mathrm{p}^{b}\left({ }^{\circ} \mathrm{C}\right)$ & $T \mathrm{c}^{\mathrm{c}}\left({ }^{\circ} \mathrm{C}\right)$ & $\Delta H^{d}(\mathrm{~J} / \mathrm{g})$ & To $\left({ }^{\circ} \mathrm{C}\right)$ & $T \mathrm{p}\left({ }^{\circ} \mathrm{C}\right)$ & $T \mathrm{c}\left({ }^{\circ} \mathrm{C}\right)$ & $\Delta H(\mathrm{~J} / \mathrm{g})$ \\
\hline Schooner & 55.1 & 58.5 & 77.3 & 12.4 & 85.4 & 97.3 & 106.1 & 2.0 \\
\hline Grimmett & 54.6 & 58.5 & 77.1 & 12.6 & 86.2 & 99.3 & 106.8 & 3.1 \\
\hline Starling & 53.6 & 56.9 & 73.5 & 12.2 & 86.4 & 98.7 & 106.5 & 1.7 \\
\hline Nishinochikara & 57.0 & 60.0 & 77.7 & 13.0 & 84.7 & 97.3 & 105.8 & 2.4 \\
\hline Minorimugi & 55.4 & 58.1 & 75.8 & 12.5 & 86.2 & 97.2 & 106.1 & 2.6 \\
\hline Hinodehadaka & 56.0 & 58.8 & 73.8 & 12.8 & 85.4 & 96.4 & 105.7 & 2.4 \\
\hline Aohadakamugi & 56.5 & 59.1 & 72.1 & 12.1 & 86.6 & 96.6 & 104.4 & 1.0 \\
\hline
\end{tabular}

${ }^{a}$ Onset temperature. ${ }^{b}$ Peak temperature. ${ }^{c}$ Complete temperature. ${ }^{d}$ Enthalpy change.

mum viscosity and breakdown but higher set back values, suggesting that barley starches had less swelling and fragility and higher gelling tendency.

\section{Gelatinization and retrogradation of starch paste.}

The $5 \%$ barley starch suspensions were heated at $100^{\circ} \mathrm{C}$ for $20 \mathrm{~min}$, and the degree of gelatinization was determined by glucoamylase digestion (DG-g) and iodine titration (DG-i) methods (Table 4). The DG-g value reflects gelatinization of whole starch and the DG-i value is specific for amylose. ${ }^{24}$ Judging from the DG-g values (98$100 \%)$, all the barley starches were almost completely gelatinized. On the other hand, DG-i values were $89-99 \%$, showing that gelatinization of the barley amyloses differed among the cultivars. Grimmett and Starling amyloses were less gelati-

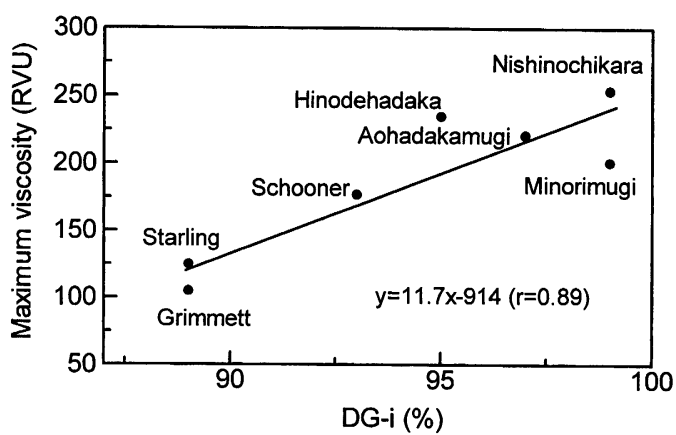

Fig. 2. Relationship between maximum viscosity and gelatinization degree of amylose (DG-i).

nized than the others, and their relatively low DG-i values were similar to those of maize and wheat starches. ${ }^{24)}$ The DG-i values showed a good correlation $(r=0.89)$ with the maximum viscosity as shown in Fig. 2. The starches with a lower DG-i 
value showed a lower maximum viscosity. The correlation suggested that the low degree of gelatinization of amylose resulted in restraint of the swelling of starch granules, and supported the results obtained for various kinds of plant starches reported by Takeda and Hizukuri. ${ }^{24}$

The retrogradation tendency of barley starch pastes during storage at $0^{\circ} \mathrm{C}$ was examined by monitoring the DG-g and DG-i values (Table 4). Both DG-g and DG-i values decreased rapidly within an hour and then slowly. This retrogradation tendency of barley starches was similar to those of the other cereal starches. ${ }^{41)}$ The DG-i values during storage at $0^{\circ} \mathrm{C}$ for $1 \mathrm{~h}$, however, varied from 43 to $67 \%$, indicating that retrogradation tendency of amylose also differed with the cultivars.

\section{Differential scanning calorimetry of starch.}

The DSC thermogram of the barley starches gave two prominent transitions in a similar temperature range (Fig. 3 and Table 5). The first (peak 1) and second (peak 2) transitions correspond to melting of starch crystallites $^{42)}$ and amylose-lipid complex, ${ }^{43)}$ respectively. In the first transition, the onset $(T o)$, peak $(T \mathrm{p})$ and complete $(T \mathrm{c})$ temperatures were $53.6-57.0^{\circ} \mathrm{C}, 56.9-60.0^{\circ} \mathrm{C}$ and $72.1-77.7^{\circ} \mathrm{C}$, respectively. Nishinochikara had slightly higher $T \mathrm{o}, T \mathrm{p}$ and $T \mathrm{c}$, while Starling had slightly lower values than the other starches. The starches had a similar enthalpy $(\Delta H, 12.1-13.0 \mathrm{~J} /$ g) and the values were lower than those for maize $^{37)}$ and wheat ${ }^{4(4)}$ starches. In the second transition, $T_{\mathrm{o}}\left(84.7-86.6^{\circ} \mathrm{C}\right), T \mathrm{p}\left(96.4-99.3^{\circ} \mathrm{C}\right)$ and $T \mathrm{c}$ $\left(104.4-106.8^{\circ} \mathrm{C}\right)$ seemed to be similar. The $\Delta H$ values ranged from $1.0 \mathrm{~J} / \mathrm{g}$ (Aohadakamugi) to 3.1 $\mathrm{J} / \mathrm{g}$ (Grimmett), implying a difference in the amount of amylose-lipid complex of the starches. The amount of the complex was estimated from the increase of IA (1.68-2.35) by defatting of starches (Table 6). However, no correlation was found $(r=0.42)$ between the $\Delta H$ values and the increase of IA. Thus, it was considered that the difference in the $\Delta H$ value for the second transition among the normal barley cultivars might be caused by other factors, such as different growth conditions $\mathrm{s}^{45)}$ and starch granule size $\mathrm{e}^{37)}$ together with the amount of amylose-lipid complex.

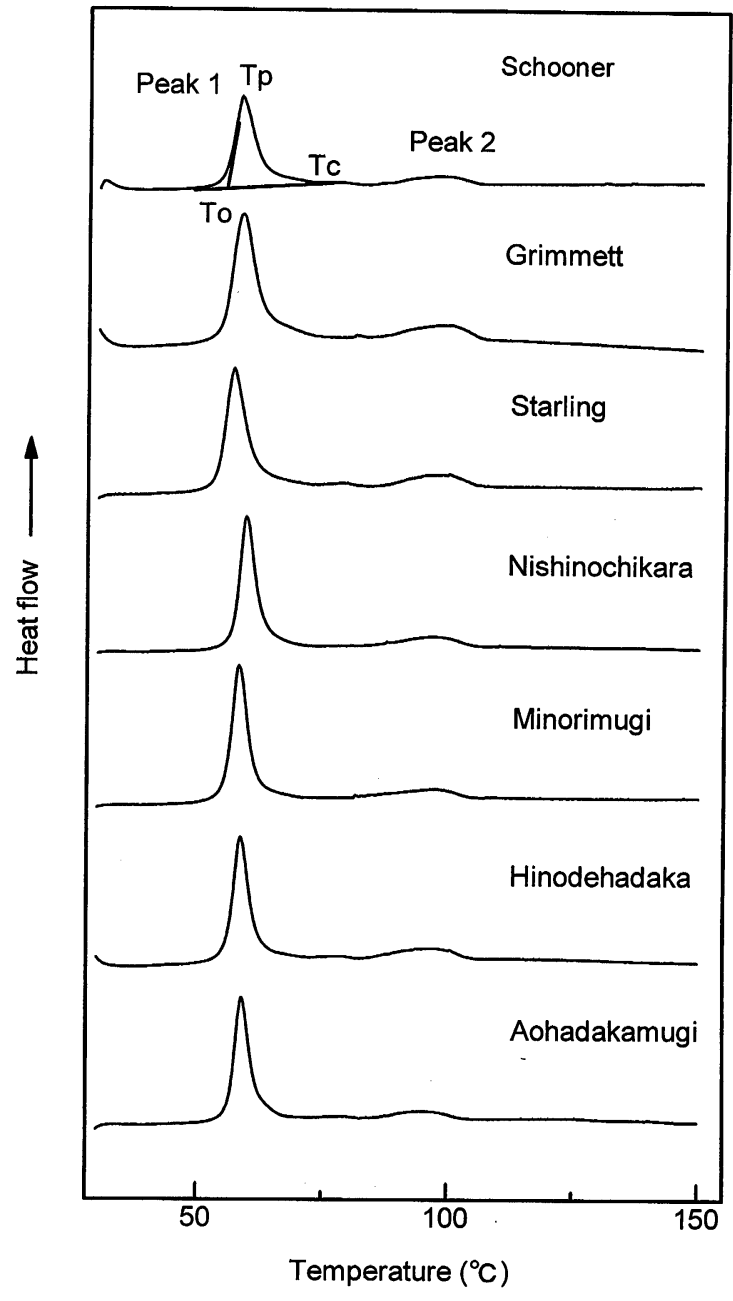

Fig. 3. DSC thermograms of barley starches.

$T \mathrm{o}, T \mathrm{p}$ and $T \mathrm{c}$ are onset, peak and complete temperatures, respectively.

Table 6. Iodine affinities of barley starches.

\begin{tabular}{lccc}
\hline \multirow{2}{*}{ Cultivar } & \multicolumn{3}{c}{ Iodine affinity, IA $(\mathrm{g} / 100 \mathrm{~g})$} \\
\cline { 2 - 4 } & $\begin{array}{l}\text { Defatted } \\
\text { starch }(A)\end{array}$ & Starch $(B)$ & $A-B$ \\
\hline Schooner & 5.69 & 3.34 & 2.35 \\
Grimmett & 5.64 & 3.77 & 1.87 \\
Starling & 5.57 & 3.40 & 2.17 \\
Nishinochikara & 5.33 & 3.65 & 1.68 \\
Minorimugi & 5.59 & 3.44 & 2.15 \\
Hinodehadaka & 5.31 & 3.03 & 2.28 \\
Aohadakamugi & 4.96 & 2.79 & 2.17 \\
\hline
\end{tabular}


Table 7. Properties of barley amylopectins.

\begin{tabular}{|c|c|c|c|c|c|c|c|}
\hline \multirow{2}{*}{ Cultivar } & \multirow{2}{*}{$\begin{array}{c}\mathrm{IA} \\
(\mathrm{g} / 100 \mathrm{~g})\end{array}$} & \multirow{2}{*}{ Blue value } & \multirow{2}{*}{$\begin{array}{l}\lambda_{\max } \\
(\mathrm{nm})\end{array}$} & \multicolumn{2}{|c|}{ Average chain-length, $\mathrm{CL}$} & \multirow{2}{*}{$\begin{array}{c}\beta-\mathrm{AL}^{c} \\
(\%)\end{array}$} & \multirow{2}{*}{$\begin{array}{c}\text { Organic } \\
\text { phosphorus } \\
(\mathrm{ppm})\end{array}$} \\
\hline & & & & Smith $^{a}$ & Iso- $^{b}{ }^{b}$ & & \\
\hline Schooner & 0.54 & 0.07 & 548 & 19 & 20 & 54 & 19 \\
\hline Grimmett & 0.70 & 0.08 & 550 & 20 & 20 & 53 & 12 \\
\hline Starling & 0.47 & 0.06 & 547 & 18 & 18 & 53 & 25 \\
\hline Nishinochikara & 0.42 & 0.06 & 542 & 18 & 19 & 54 & 11 \\
\hline Minorimugi & 0.64 & 0.07 & 549 & 18 & 18 & 52 & 37 \\
\hline Hinodehadaka & 0.69 & 0.07 & 549 & 18 & 18 & 52 & 17 \\
\hline Aohadakamugi & 0.61 & 0.06 & 547 & 18 & 18 & 53 & 13 \\
\hline
\end{tabular}

${ }^{a}$ Determined by the rapid Smith degradation method. ${ }^{b}$ Determined by the isoamylolysis method. ${ }^{c} \beta$-Amylolysis limit.

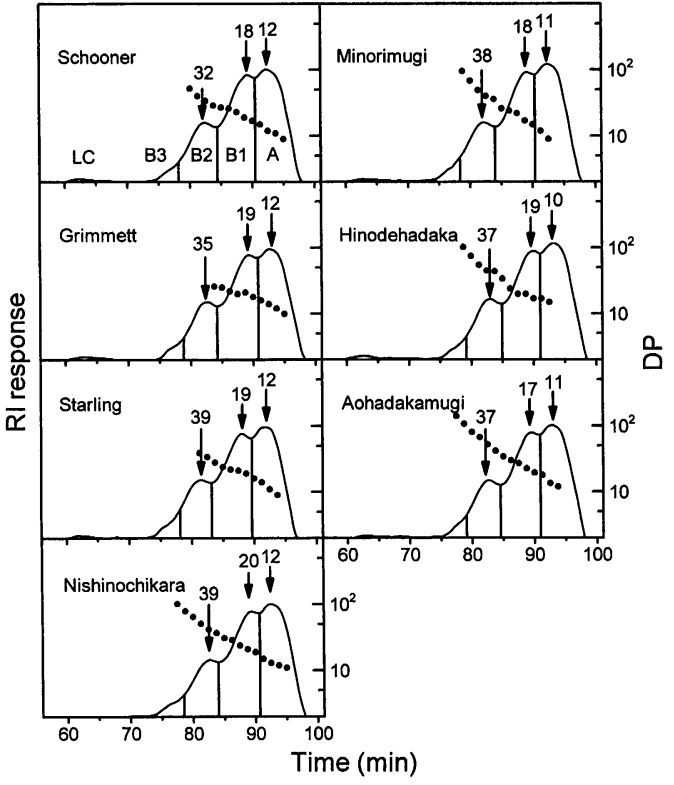

Fig. 4. Gel-permeation HPLC chromatograms of barley amylopectins after isoamylolysis.

-, differential refractometry; $\bullet$, DP.

\section{Structure of amylopectin.}

Table 7 summarizes the properties of the barley amylopectins. The amylopectins from all the cultivars were similar in IA $(0.42-0.70 \mathrm{~g} / 100 \mathrm{~g})$, blue value $(0.06-0.08)$ and $\lambda_{\max }(542-550 \mathrm{~nm})$. The IA values were lower than those for maize amylopectins $(0.80-1.10 \mathrm{~g} / 100 \mathrm{~g})^{2,3)}$ and similar or lower than those for rice $(0.39-2.57 \mathrm{~g} / 100 \mathrm{~g})^{5,6)}$ and wheat $(0.40-1.12 \mathrm{~g} / 100 \mathrm{~g})^{7,8)}$ amylopectins. The CL was 18-20 and Schooner and Grimmett amylopectins had a slightly larger CL than the others. These values were comparable to those of japonica rice $(19-20)^{5)}$ and wheat $(19-21)^{7,8)}$ amylopectins, but slightly lower than those of maize $(21-22)^{2,3)}$ and indica rice $(21-22)^{5,6)}$ amylopectins. The barley amylopectins had a lower $\beta$-amylolysis limit $(52-54 \%)$ than maize $(59 \%))^{2,3)}$ rice $(56-59 \%)^{5,6)}$ and wheat $(56-59 \%)^{7,8)}$ amylopectins. The amount of phosphorus (11-37 ppm) of the barley amylopectins was similar to those of maize (15 ppm) ${ }^{2)}$ rice (5-29 $\mathrm{ppm})^{5,6)}$ and wheat $(4-20 \mathrm{ppm})^{7,8)}$ amylopectins.

Table 8. Carbohydrate amounts and weight-average chain length (CLw) of the fractions of isoamylase-debranched amylopectins.

\begin{tabular}{|c|c|c|c|c|c|c|c|c|c|c|}
\hline \multirow{2}{*}{ Cultivar } & \multicolumn{5}{|c|}{ Amount ( $\%$ of total) } & \multicolumn{5}{|c|}{ CLw } \\
\hline & LC & B3 & B2 & B1 & A & B3 & B2 & B1 & A & $\Sigma(B 3-A)$ \\
\hline Schooner & 1 & 5 & 17 & 36 & 41 & 118 & 37 & 20 & 11 & 24 \\
\hline Grimmett & 1 & 5 & 16 & 37 & 41 & 110 & 39 & 21 & 12 & 25 \\
\hline Starling & 1 & 6 & 16 & 36 & 41 & 115 & 42 & 20 & 12 & 26 \\
\hline Nishinochikara & 0 & 6 & 16 & 36 & 42 & 99 & 46 & 24 & 13 & 27 \\
\hline Minorimugi & 1 & 5 & 17 & 35 & 42 & 96 & 44 & 21 & 11 & 24 \\
\hline Hinodehadaka & 1 & 5 & 17 & 35 & 42 & 118 & 40 & 21 & 12 & 24 \\
\hline Aohadakamugi & 1 & 5 & 17 & 35 & 42 & 102 & 40 & 21 & 10 & 24 \\
\hline
\end{tabular}


Figure 4 shows the chain-length distribution of barley amylopectins after debranching with isoamylase. The chains were fractionated into LC, B 3, B2, B1 and A, in the order of elution. ${ }^{31)}$ All the amylopectins resembled each other in chain-length distribution and carbohydrate amount of each fraction, although the weight-average chain length of each fraction was somewhat different (Table 8). The LC fraction was absent in Nishinochikara amylopectin but present in the other amylopectins in a very small amount $(1 \%)$. The relationship between the amount of LC fraction and the IA of amylopectins was consistent with the results for rice amylopectins. ${ }^{5}$ ) The amount of long chains (LC+B3) was 6-7\% for the barley amylopectins, being lower than those for maize $(10 \%)^{2)}$ and rice $(7-20 \%)^{5,6)}$ amylopectins but similar to those for wheat amylopectins $(5-10 \%){ }^{7,8)} \mathrm{B} 1$ and A-chains fractions of all the amylopectins showed individual peaks. This elution profile, together with the results for other normal barley cultivars, ${ }^{9-12)}$ was considered to be characteristic in barley amylopectins. This profile was also similar to those of wheat amylopectins, ${ }^{7,8)}$ and differed from those of maize and rice amylopectins ${ }^{2,56}$ since these amylopectins showed B1 and A-chains fractions as a peak. The distribution of short chains was clarified by HPAEC (Fig. 5). The barley amylopectins showed a similar chain-length distribution among the cultivars with a peak at DP 11-12 and an apparent shoulder at DP 18 . This result was in agreement with those obtained by gel-permeation HPLC although the peak and shoulder DP was somewhat different. These distributions were also similar to those of other normal barley, ${ }^{9,10,1232}$ and wheat ${ }^{8,32)}$ amylopectins, but slightly different from maize and rice amylopectins. ${ }^{32}$

\section{Structure of amylose.}

Table 9 summarizes the properties of the barley amyloses. The IA was in the range of 18.5-19.7 $\mathrm{g} / 100 \mathrm{~g}$. These values were slightly lower than those of maize $(20.1-21.3 \mathrm{~g} / 100 \mathrm{~g})^{2,3)}$ and rice $(20.1-21.1 \mathrm{~g} / 100 \mathrm{~g})^{4,6)}$ amyloses. The blue value and $\lambda_{\max }$ were $1.43-1.51$ and $644-655 \mathrm{~nm}$, re-

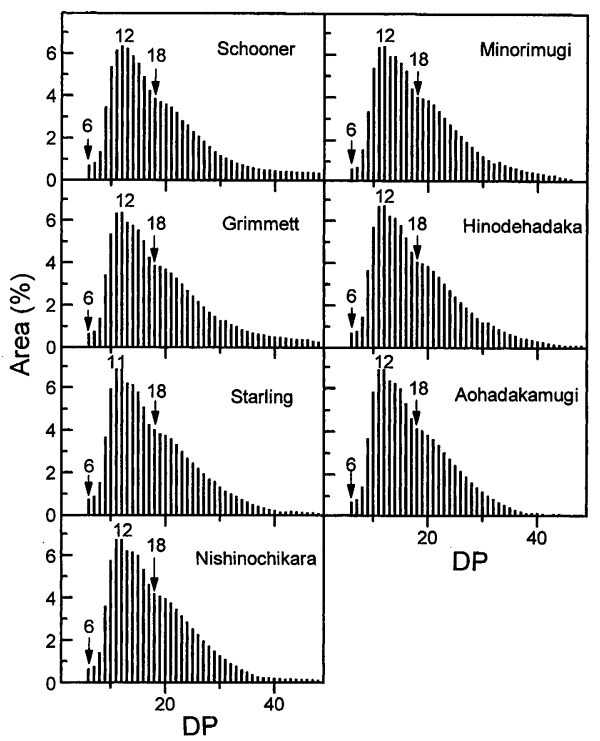

Fig. 5. Chain-length distribution of barley amylopectins by HPAEC.

Table 9. Properties of barley amyloses.

\begin{tabular}{|c|c|c|c|c|c|c|c|c|c|c|}
\hline Cultivar & $\begin{array}{c}\text { IA } \\
(\mathrm{g} / 100 \mathrm{~g})\end{array}$ & $\begin{array}{l}\text { Blue } \\
\text { value }\end{array}$ & $\begin{array}{l}\lambda_{\max } \\
(\mathrm{nm})\end{array}$ & $\begin{array}{l}\text { Number- } \\
\text { average } \\
\text { DP, DPn }\end{array}$ & $\begin{array}{l}\text { Weight- } \\
\text { average } \\
\text { DP, DPw }\end{array}$ & $\mathrm{DPw} / \mathrm{DPn}$ & $\begin{array}{l}\text { Apparent DP } \\
\text { distribution }^{a}\end{array}$ & $\mathrm{CL}$ & $\begin{array}{c}\beta-A L \\
(\%)\end{array}$ & $\begin{array}{c}\text { Average } \\
\text { number of } \\
\text { chains }\end{array}$ \\
\hline Schooner & 19.0 & 1.45 & 649 & 1000 & 4240 & 4.2 & $350-18000$ & 270 & 79 & 3.7 \\
\hline Grimmett & 19.1 & 1.51 & 648 & 1090 & 5020 & 4.6 & $410-22000$ & 240 & 74 & 4.5 \\
\hline Starling & 19.8 & 1.47 & 644 & 810 & 2450 & 3.0 & $260-11000$ & 220 & 79 & 3.7 \\
\hline Nishinochikara & 19.7 & 1.47 & 646 & 870 & 2990 & 3.4 & $340-14000$ & 240 & 80 & 3.6 \\
\hline Minorimugi & 19.1 & 1.51 & 652 & 1180 & 6440 & 5.5 & $540-22000$ & 310 & 80 & 3.8 \\
\hline Hinodehadaka & 19.5 & 1.47 & 653 & 1320 & 5140 & 3.9 & $360-18000$ & 360 & 78 & 3.7 \\
\hline Aohadakamugi & 18.5 & 1.43 & 655 & 1410 & 6030 & 4.3 & $690-22000$ & 270 & 80 & 5.2 \\
\hline
\end{tabular}

${ }^{a}$ DP values of the subfractions ( $10 \%$ by weight) having the lowest and highest molecular weights. 


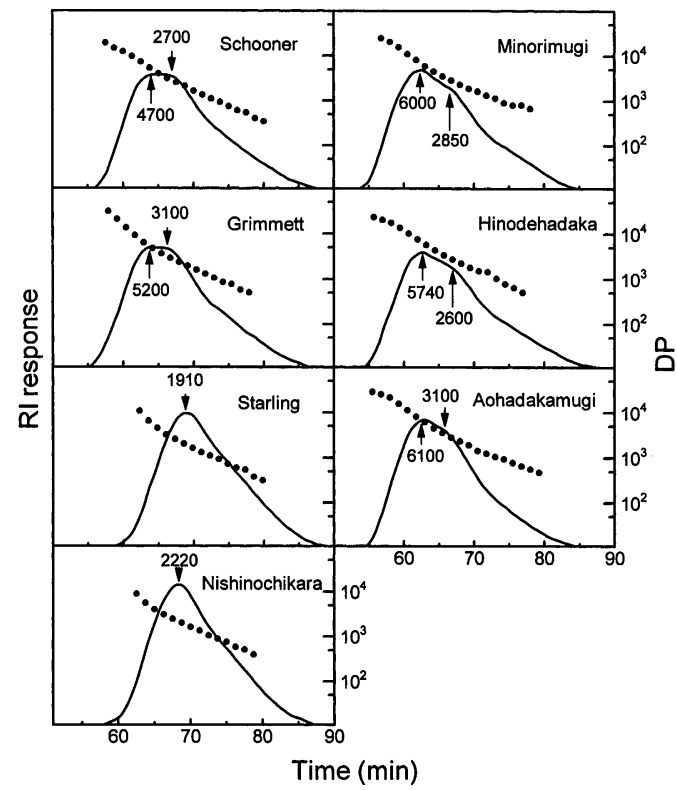

Fig. 6. Gel-permeation HPLC chromatograms of barley amyloses.

— and $\bullet$, differential refractometry and DP, respectively.

spectively. The number- (DPn) and weight- (DPw) average degree of polymerization were $810-1410$ and 2450-6440, respectively, and Minorimugi amylose was largest in molecular size and Starling amylose was smallest. Other normal barley amyloses had DPn of 1110-1570 and DPw of 3440$5580 .^{9-12)}$ Thus, barley amyloses were different in molecular size with the cultivar. These molecular sizes were similar to wheat amyloses $(\mathrm{DPn}=830$ $1570, \mathrm{DPw}=2360-5450),{ }^{7,8)}$ but, in general, larger than those for maize $\left(\mathrm{DPn}=830-990, \mathrm{DPw}=2500^{-}\right.$ $2680)^{2,3)}$ and rice $(\mathrm{DPn}=920-1110, \mathrm{DPw}=2750$ $3230)^{4,6)}$ amyloses. HPLC gel-permeation chromatography (Fig. 6) of the barley amyloses gave a different elution profile with the cultivars. It was evident that Schooner, Grimmett, Minorimugi, Hinodehadaka and Aohadakamugi amyloses were composed of two components because the elution profiles showed a flat top peak or a shoulder. Starling and Nishinochikara amyloses seemed to have a single component. The higher DPw/DPn value indicates higher polydispersity of an amylose population and in fact the apparent DP distribution for Minorimugi (DPw/DPn=5.5) was wider than that for Starling amylose (3.0). The values suggested that barley amyloses had generally wider DP distribution than maize $(2.5)^{2)}$ and rice (2.6$3.9)^{4,6)}$ amyloses, and similar to wheat amyloses $(2.8-5.0){ }^{7.8)}$ The average number of chains per molecule (NC) was 3.6-5.2, which was higher or similar to those of other normal barley amyloses $\left(\mathrm{NC}=1.8,3.7,5.0\right.$ and 5.4) ${ }^{9-12)}$ while the NC values were 2.4-2.9 for maize, ${ }^{2,3)} 4.4-6.5$ for wheat $^{7,8)}$ and 2.5-4.3 for rice ${ }^{4,6)}$ amyloses. The barley amyloses had $\beta$-amylolysis limit of $74-80 \%$, which were slightly lower than those for maize (81$84 \%)^{2,3)}$ and wheat $(79-86 \%)^{7.8)}$ amyloses, and similar to those of some cultivars of rice amyloses $(73-87 \%){ }^{4,6)}$

In conclusion, barley starches were similar to wheat starches in amylose content and molecular structure, such as molecular size of amylose and chain-length distribution of amylopectin, among the cereal starches. As compared with maize and rice starches, barley starches had a higher amylose content, and their amyloses were generally larger molecules. Barley amylopectins differed from maize and rice amylopectins in some structural properties, especially in the distribution of short chains.

\section{REFERENCES}

1) A.W. MacGregor and G.B. Fincher: Carbohydrates of barley grain. in Barley: Chemistry and Technology, A. W. MacGregor and R.S. Bhatty, eds., American Association of Cereal Chemists, St. Paul, pp. 73-74 (1993).

2 ) Y. Takeda, T. Shitaozono and S. Hizukuri: Molecular structure of corn starch. Starch/Stärke, 40, 51-54 (1988).

3 ) Y. Takeda and J. Preiss: Structures of B90 (sugary) and W64A (normal) maize starches. Carbohydr. Res., 240, 265-275 (1993).

4 ) Y. Takeda, S. Hizukuri and B.O. Juliano: Purification and structure of amylose from rice starch. Carbohydr. Res., 148, 299-308 (1986).

5 ) Y. Takeda, S. Hizukuri and B.O. Juliano: Structures of rice amylopectins with low and high affinities for iodine. Carbohydr. Res., 168, 79-88 (1987).

6 ) Y. Takeda, N. Maruta, S. Hizukuri and B.O. Juliano: Structures of indica rice starches (IR48 and IR64) having intermediate affinities for iodine. Carbohydr. Res., 187, 287-294 (1989).

7 ) K. Shibanuma, Y. Takeda, S. Hizukuri and S. Shibata: 
Molecular structures of some wheat starches. Carbohydr. Polym., 25, 111-116 (1994).

8 ) K. Shibanuma, Y. Takeda and S. Hizukuri: Molecular and pasting properties of some wheat starches. Carbohydr. Polym., 29, 253-261 (1996).

9 ) Y. Yoshimoto, J. Tashiro, T. Takenouchi and Y. Takeda: Molecular structure and some physicochemical properties of high-amylose barley starches. Cereal Chem., 77, 279-285 (2000).

10) Y. Yoshimoto, T. Takenouchi and Y. Takeda: Molecular structure and some physicochemical properties of waxy and low-amylose barley starches. Carbohydr. Polym., in press (2001).

11) H. Schulman, S. Tomooka, A. Suzuki, P. Myllarinen and S. Hizukuri: Structural analysis of starch from normal and shx (shrunken endosperm) barley (Hordeum vulgare L.). Carbohydr. Res., 275, 361-369 (1995).

12) Y. Takeda, C. Takeda, H. Mizukami and I. Hanashiro: Structures of large, medium and small granules of barley grain. Carbohydr. Polym., 38, 109-114 (1999).

13) W. Banks, C.T. Greenwood and J.T. Walker: Studies on the starches of barley genotypes. A comparison of the starches from normal and high-amylose barley. Starch/Stärke, 23, 12-15 (1971).

14) W. Banks, C.T. Greenwood and D.D. Muir: Studies on the biosynthesis of starch granules. Part 5. Properties of the starch components of normal barley, and barley with starch of high amylose-content, during growth. Starch/Stärke, 25, 153-157 (1973).

15) A.W. MacGregor and J.E. Morgan: Structure of amylopectins isolated from large and small starch granules of normal and waxy barley. Cereal Chem., 61, 222228 (1984).

16) M.Y. Kang, Y. Sugimoto, S. Sakamoto and H. Fuwa: Developmental changes in the amylose content of endosperm starch of barley (Hordeum vulgare L.) during the grain filling period after anthesis. Agric. Biol. Chem., 49, 3463-3466 (1985).

17) R.F. Tester and W.R. Morrison: Swelling and gelatinization of cereal starches. III. Some properties of waxy and normal nonwaxy barley starches. Cereal Chem., 69, 654-658 (1992)

18) Z. Czuchajowska, A. Klamczynski, B. Paszczynska and B.-K. Baik: Structure and functionality of barley starches. Cereal Chem., 75, 747-754 (1998).

19) S. Lansky, M. Kooi and T.J. Schoch: Properties of the fractions and linear subfractions from various starches. J. Am. Chem. Soc., 71, 4066-4075 (1949).

20) Y. Takeda, K. Shirasaka and S. Hizukuri: Examination of the purity and structure of amylose by gelpermeation chromatography. Carbohydr. Res., 132, 83-92 (1984)

21) J.J. Marshall and W.J. Whelan: Removal of $\alpha$ glucosidase impurity from crystalline sweet-potato $\beta$ amylase. Anal. Biochem., 52, 642-646 (1973).
22) B.L. Larson, K.A. Gilles and R. Jennes: Amperometric method for determining the sorption of iodine by starch. Anal. Chem., 25, 802-804 (1953).

23) S. Hizukuri, Y. Takeda, T. Shitaozono, J. Abe, A. Ohtakara, C. Takeda and A. Suzuki: Structure and properties of water chestnut (Trapa natans L. var. bispinosa Makino) starch. Starch/Stärke, 40, 165-171 (1988).

24) C. Takeda and S. Hizukuri: Characterization of the heat dependent pasting behavior of starches. Nippon Nogei Kagaku Kaishi, 48, 663-669 (1974).

25) A. Suzuki, S. Hizukuri and Y. Takeda: Physicochemical studies of kuzu starch. Cereal Chem., 58, 286-290 (1981).

26) C. Takeda, Y. Takeda and S. Hizukuri: Physicochemical properties of lily starch. Cereal Chem., 60, 212216 (1983).

27) S. Hizukuri and S. Osaki: A rapid Smith-degradation for the determination of non-reducing, terminal residues of $(1 \rightarrow 4)-\alpha$-D-glucans. Carbohydr. Res., 63, 261264 (1978).

28) S. Hizukuri, Y. Takeda, M. Yasuda and A. Suzuki: Multi-branched nature of amylose and the action of debranching enzymes. Carbohydr. Res., 94, 205-213 (1981).

29) C.H. Fiske and Y. Subbarow: The colorimetric determination of phosphorus. J. Biol. Chem., 66, 375-400 (1925).

30) R.J.L. Allen: The estimation of phosphorus. Biochem. J., 34, 858-865 (1940).

31) S. Hizukuri: Polymodal distribution of the chain lengths of amylopectins, and its significance. Carbohydr. Res., 147, 342-347 (1986).

32) I. Hanashiro, J. Abe and S. Hizukuri: A periodic distribution of the chain length of amylopectin as revealed by high-performance anion-exchange chromatography. Carbohydr. Res., 283, 151-159 (1996).

33) S. Hizukuri and T. Takagi: Estimation of the distribution of molecular weight for amylose by the low-angle laser-light-scattering technique combined with highperformance gel chromatography. Carbohydr. Res. 134, 1-10 (1984).

34) M. Dubois, K.A. Gilles, J.K. Hamilton, P.A. Rebers and F. Smith: Colorimetric method for determination of sugars and related substances. Anal. Chem., 28, 350-356 (1956).

35) S. Hizukuri, T. Kaneko and Y. Takeda: Measurement of the chain length of amylopectin and its relevance to the origin of crystalline polymorphism of starch granules. Biochim. Biophys. Acta, 760, 188-191 (1983).

36) K.J. Goering and B. Dehaas: A comparison of the properties of large- and small-granule starch isolated from several isogenic lines of barley. Cereal Chem., 51, 573-578 (1974).

37) T. Vasanthan and R.S. Bhatty: Physicochemical properties of small- and large-granule starches of waxy, regular, and high-amylose barleys. Cereal Chem., 73, 
199-207 (1996).

38) Y. Song and J. Jane: Characterization of barley starches of waxy, normal, and high amylose varieties. Carbohydr. Polym., 41, 365-377 (2000).

39) I.A. Jideani, Y. Takeda and S. Hizukuri: Structures and physicochemical properties of starches from acha (Digitaria exilis), iburu (D. iburua), and tamba (Eleusine coracana). Cereal Chem., 73, 677-685 (1996).

40) H. Mizukami, S. Hizukuri and Y. Takeda: Structures and pasting properties of starches from new characteristic rice cultivars. Oyo Toshitsu Kagaku, 43, 15-23 (1996).

41) C. Takeda: Functions of gelatinization and retrogradation and molecular structures of starches. Ph. D. Thesis, Kagoshima University, pp. 99-100 (1996).

42) W.R. Morrison, R.F. Tester, C.E. Snape, R. Law and M.J. Gidley: Swelling and gelatinization of cereal starch. IV. Some effects of lipid-complexed amylose and free amylose in waxy and normal barley starches. Cereal Chem., 70, 385-391 (1993).

43) M. Kugimiya, J.W. Donovan and R.G. Wong: Phase transitions in amylose-lipid complexes in starch: A calorimetric study. Starch/Stärke, 32, 265-270 (1980).

44) H. Fredriksson, J. Silverio, R. Andersson, A.-C. Eliasson and P. Aman: The influence of amylose and amylopectin characteristics on gelatinization and retrogradation properties of different starches. Carbohydr. Polym., 35, 119-134 (1998).

45) R.F. Tester, J.B. South, W.R. Morrison and R.P. Ellis: The effect of ambient temperature during the grain fillin period on the composition and properties of starch from four barley genotypes. J. Cereal Sci., 13, 113127 (1991).

(Received April 9, 2001; Accepted May 15, 2001)
普通種大麦澱粉の分子構造と糊化特性

吉元 寧 ${ }^{1,2}$, 花城 勲 ${ }^{3}$, 竹之内忠廣 ${ }^{2}$, 竹田靖史 ${ }^{3}$

$$
\begin{gathered}
{ }^{1} \text { 鹿児島大学大学院連合農学研究科 } \\
(890-0065 \text { 鹿児島市郡元 } 1-21-24) \\
2 \text { 竹之内穀類産業株式会社 } \\
(891-0122 \text { 鹿照島市南栄 } 4-12-4) \\
{ }^{3} \text { 鹿児島大学農学部生物資源化学科 } \\
(890-0065 \text { 鹿児島市郡元 } 1-21-24)
\end{gathered}
$$

7 品種の普通種大麦澱粉の分子構造と糊化特性を調 ベ, トウモロコシ, 米, 小麦澱粉と比較した. 大麦澱 粉は真のアミロース含量が 24.3-27.9\%であった. 糊 化特性では, 品種間で最高粘度やブレークダウン, ア ミロースの糊化度などに相違が認められた. 最高粘度 とアミロースの糊化度の間に正の相関が認められ，ア ミロースの糊化が低いほど澱粉粒の膨潤が抑制される ことが示唆された.アミロペクチンはヨウ素親和力が 低く $(0.42-0.70 \mathrm{~g} / 100 \mathrm{~g})$, 鎖長分布は互いに類似し，A 鎖と B1 鎖が明確に分かれた.アミロースは数平均重 合度が 810-1410, 平均鎖数は 3.6-5.2で, 品種間で分 子構造が異なっていた。穀類澱粉の中で，大麦澱粉は 小麦澱粉とアミロース含量や分子構造, とくにアミ ロース分子の大きさとアミロペクチンの鎖長分布が類 似していた. 